\title{
Sperm morphology and cytogenetic studies in ageing C57BL/6 mice
}

\author{
Jill D. Fabricant and T. A. Parkening* \\ Departments of Preventive Medicine and Community Health, Human Genetics and Cell Biology \\ and *Anatomy, The University of Texas Medical Branch at Galveston, Galveston, \\ Texas 77550 , U.S.A.
}

\begin{abstract}
Summary. A dose-response relationship was observed in the percentage of morphologically abnormal spermatozoa as a function of age for 2-, 6-, 12-, 18- and 25-month-old C57BL/6 male mice. Compared with values for younger mice, 25 -month-old mice had a significantly $(P<0.005)$ higher percentage of abnormal spermatozoa $(23.9 \pm 2.3 \%)$ and the percentages in mice aged $12(12.9 \pm 0.7 \%)$ and $18(14.3 \pm 1.3 \%)$ months were significantly $(P<0.05)$ different from those of 2 -month-old animals $(10.5 \pm 0.7 \%)$. Significant differences were not observed in the cytogenetic studies for 6-, 12-, 18- and 25-month-old mice, although 2-month-old mice had a lower frequency $(P<0.05)$ of chromosomal aberrations compared to 12- and 18-month-old animals.
\end{abstract}

\section{Introduction}

A relationship has been shown between paternal ageing and certain human diseases, such as achondroplasia, Apert syndrome, Marfan syndrome and fibrodysplasia ossificans progressiva (Tunte, Becker \& Von Knorre, 1967; Murdock, Walker \& McKusick, 1972; Smith, 1972; Erickson \& Cohen, 1974). While the aetiological basis of these disorders is still unknown, it has been suggested that accumulated exposure to mutagenic chemical agents and increased susceptibility to mutation of spermatogonial stem cells from aged men may be causes. The 'cyclic' epidemic pattern for Down's syndrome may also be explained by male transmission, in that differential rates of environmentally induced chromosomal non-disjunction occur in male germ cells and not in females (Bennett \& Abroms, 1979). In a clinical study of over 1500 men ranging from 20 to 50 years of age, it was reported that the ease with which conception is achieved decreases after 25 years (MacLeod \& Gold, 1953). MacLeod \& Gold (1953) did not observe a relationship between age and sperm morphology, but Natoli, Riondino \& Brancati (1972) reported that the number of normal spermatozoa (motility and morphology) per ejaculate decreased with age in men 45-91 years of age.

Among certain strains of mice an increased frequency of morphologically aberrant spermatozoa are associated with early maturity (Krzanowska, 1972) and the number of spermatozoa of normal appearance increased from 2.8 to $82.2 \%$ in 6 - and 10 -week-old C57BL/Kw mice, respectively (Krzanowska, 1981). However, whether sperm head morphology is altered in senescent male mice has not been adequately examined. Krzanowska (1981) reported that the percentage of normal spermatozoa in one 15 -month-old KE mouse was $61 \cdot 5 \%$ compared to $81.3 \%$ found in five 3 -month-old $\mathrm{KE}$ mice. In this same study 10 -month-old $\mathrm{CBA} / \mathrm{Kw}$ mice had $90.4 \%$ normal spermatozoa compared to $93.2 \%$ in 10 -week-old mice. Since some abnormal spermatozoa are viable and may be capable of fertilization, thereby contributing to the paternal age effect, it was of interest to determine whether the sperm population was affected in older mice. 


\section{Materials and Methods}

Male C57BL/6 mice were obtained from Charles River Breeding Laboratories, Wilmington, Massachusetts, and aged at The University of Texas Medical Branch, Galveston, Texas. The mice were housed under artificial lighting (lights on 06:00-20:00 h) and provided with food and water ad libitum.

Sperm morphology. The cauda epididymidis was removed from each side and minced in a phosphate-buffered saline solution (PBS) and passed through an 80-mesh stainless-steel filter. Smears were made of the suspension and allowed to dry in air. Slides were stained in $1 \%$ eosin-Y solution for $45 \mathrm{~min}$. A total of 666 spermatozoa was observed at $\times 480$ for each animal; the spermatozoa were scored 'blind' as normal or abnormal, and abnormal spermatozoa were classified according to the criteria established by Wyrobek \& Bruce (1978) but the specific type of abnormality was not categorized within each group. Only intact spermatozoa were included in the analyses. All slides were scored by the same individual.

Cytogenetics. Each animal was injected with $2 \mathrm{mg}$ colcemid $/ \mathrm{kg} 2 \mathrm{~h}$ before death. Bone marrow was flushed from both femurs of each mouse with PBS in a 1-ml syringe (30-gauge needle). The cells were then collected by centrifugation at $5000 \mathrm{~g}$ for $5 \mathrm{~min}$ and resuspended in a hypotonic solution $(0.075 \mathrm{M}-\mathrm{KCl})$ for $18 \mathrm{~min}$ at $37^{\circ} \mathrm{C}$. They were then recentrifuged and fixed in Carnoy's fluid (methanol:acetic acid, 3:1 v/v). Air-blown slides were prepared and stained in a $2 \%$ Giemsa solution. When possible, 100 metaphase cells were analysed per animal.

Histology. After excision of the caudae, the testes of each mouse were removed, weighed and fixed in $10 \%$ neutral formalin or Bouin's fluid. After dehydration, embedding in paraffin wax, sectioning at $5 \mu \mathrm{m}$ and staining with haematoxylin and eosin, the slides were examined for morphological differences.

\section{Results}

The data in Table 1 demonstrate that there was a progressive increase in the percentage of abnormal spermatozoa with age. The percentage of aberrant metaphases was not different in 6 to 25-month-old mice, but the frequency of chromosome breaks in 2-month-old mice was significantly lower than that in all other age groups (Table 2). Testicular weight increased up to 12 months of age and then declined (Table 1). The testes from most 25 -month-old mice were not as firm or turgid as those of mice in the other age groups. Histologically it was apparent that the

Table 1. Effects of ageing on the percentage of morphologically abnormal spermatozoa in C57BL/6 mice

\begin{tabular}{|c|c|c|c|c|c|}
\hline \multirow{2}{*}{$\begin{array}{c}\text { Age } \\
\text { (months) }\end{array}$} & \multirow{2}{*}{$\begin{array}{l}\text { No. of } \\
\text { mice }\end{array}$} & \multirow{2}{*}{$\begin{array}{c}\text { Mean ( } \pm \text { s.e.m.) } \\
\text { wt of testes } \\
(\mathrm{mg})\end{array}$} & \multicolumn{2}{|c|}{ No. of spermatozoa } & \multirow{2}{*}{$\begin{array}{c}\text { Mean ( } \pm \text { s.e.m.) } \\
\% \text { aberrations }\end{array}$} \\
\hline & & & Analysed & Abnormal & \\
\hline 2 & 8 & $151 \cdot 3 \pm 9 \cdot 0$ & 5328 & 561 & $10 \cdot 52 \pm 0.72$ \\
\hline 6 & 8 & $183.5 \pm 3.4^{*}$ & 5328 & 650 & $12 \cdot 20 \pm 1 \cdot 00$ \\
\hline 12 & 8 & $193.2 \pm 5 \cdot 1^{*}$ & 5328 & 686 & $12.88 \pm 0.72^{*}$ \\
\hline 18 & 8 & $159.0 \pm 7.9 \dagger$ & 6400 & 986 & $14 \cdot 30 \pm 1 \cdot 30^{*}$ \\
\hline 25 & 5 & $140.8 \pm 12.5 \dagger$ & 3330 & 796 & $23 \cdot 90 \pm 2 \cdot 30 \pm \S$ \\
\hline
\end{tabular}

* Significantly different from value for 2 -month-old mice: $P<0.05$.

+ Significantly different from values for 6 - and 12 -month-old mice: $P<0.01$.

$\ddagger$ Significantly different from values for $2-, 6$ - and 12 -month-old mice: $P<0.001$.

$\S$ Significantly different from value for 18 -month-old mice: $P<0.005$. 

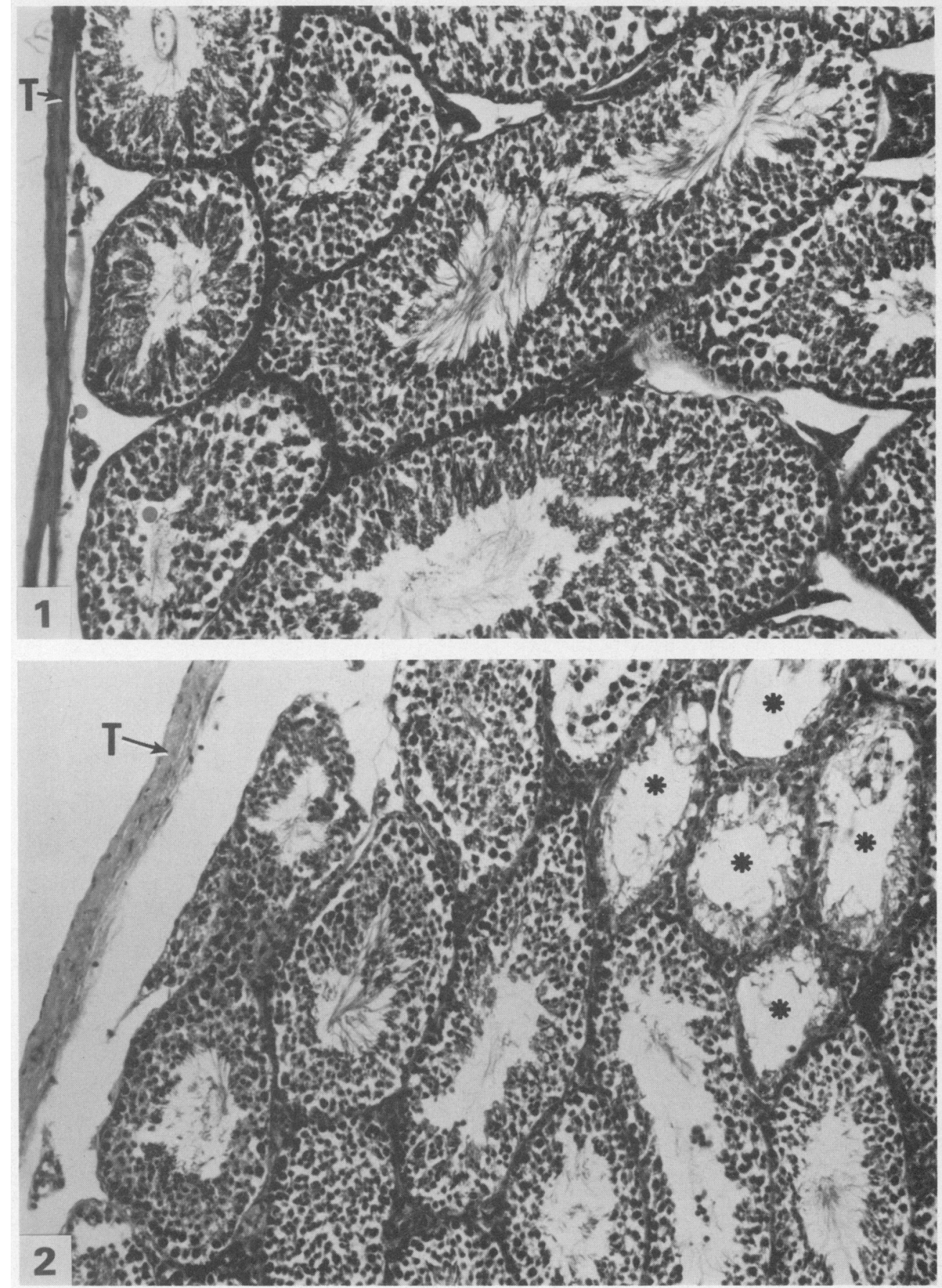

Fig. 1. Tunica aibuginea ( $\mathrm{T}$ ) and seminiferous tubules from the testis of a 6 -month-old C $57 \mathrm{BL} / 6$ mouse. $\times 160$.

Fig. 2. Tunica albuginea $(T)$ and seminiferous tubules from the testis of a 25 -month-old C $57 \mathrm{BL} / 6$ mouse. The tunica albuginea is thicker than in testes of younger mice (Fig. 1) and the epithelium of some of the seminiferous tubules has degenerated $\left(^{*}\right) . \times 160$. 
Table 2. Effects of ageing on the percentage of chromosomal aberrations in the bone marrow of $\mathrm{C} 57 \mathrm{BL} / 6$ mice

\begin{tabular}{|c|c|c|c|c|c|c|c|c|}
\hline \multirow[b]{2}{*}{$\begin{array}{c}\text { Age } \\
\text { (months) }\end{array}$} & \multirow{2}{*}{$\begin{array}{l}\text { No. } \\
\text { of } \\
\text { mice }\end{array}$} & \multirow[b]{2}{*}{$\begin{array}{c}\text { No. of } \\
\text { metaphases }\end{array}$} & \multicolumn{5}{|c|}{ No. of metaphases with } & \multirow{2}{*}{$\begin{array}{c}\text { Mean }( \pm \text { s.e.m.) } \\
\% \text { aberrant } \\
\text { metaphases }\end{array}$} \\
\hline & & & Gaps & $\begin{array}{l}\text { Breaks, } \\
\text { fragments }\end{array}$ & Exchanges & Deletions & $\begin{array}{c}\text { Multiple } \\
\text { aberrations }\end{array}$ & \\
\hline 2 & 8 & 769 & 0 & 1 & 0 & 0 & 0 & $0.13 \pm 0.13$ \\
\hline 6 & 8 & 689 & 0 & 8 & 3 & 0 & 0 & $1.64 \pm 0.68$ \\
\hline 12 & 8 & 523 & 0 & 7 & 4 & 0 & 0 & $2.02 \pm 0.72^{*}$ \\
\hline 18 & 8 & 684 & 2 & 8 & 3 & 0 & 2 & $1.81 \pm 0.55^{*}$ \\
\hline 25 & 5 & 850 & 0 & 17 & 2 & 0 & 0 & $2.24 \pm 0.77$ \\
\hline
\end{tabular}

* Significantly different from value for 2 -month-old mice: $P<0.05$.

tunica albuginea was thicker in 25- than in 2- and 6-month-old mice. Some of the seminiferous tubules in testes of 25-month-old mice were abnormal in that there was an absence of spermatogenesis (Pl. 1, Figs 1 and 2).

\section{Discussion}

The present results of increased sperm head aberrations as a function of ageing are consistent with a theory of decreased repair ability in cells from aged animals (Alexander, 1967). While spermatogenesis is a continuing event involving a constant turnover of germ cells, the germ cells are still derived from an aged animal. Hence, the increase in aberrations could reflect DNA repair deficiencies in the germ cells from the aged animals. Unscheduled DNA synthesis which reffects DNA repair has been identified in pre-meiotic germ cells (Sotomayor, Sega \& Cumming, 1979), although age-related studies have not yet been reported. If sister chromatid exchange represents a form of DNA repair (Latt, 1974), then there could be decreased DNA repair ability in ageing cell populations because the frequencies of induced sister chromatid exchange by mitomycin $\mathrm{C}$ are higher in human cell cultures of younger donors than in those from older donors (Schneider \& Gilman, 1979). Similar results have been obtained from in-vitro studies on human diploid fibroblasts at different stages of cellular passage (Schneider \& Monticone, 1978) and from in-vivo studies on ageing mice (Kram, Schneider, Tice \& Gianas, 1978). Other reports have indicated that cellular DNA lesions such as strand breaks (Price, Modak \& Makinodan, 1971), DNA-protein crosslinks (Archarya, 1972) and spontaneous aberrations (Curtis \& Miller, 1971) may be more frequent in ageing cell populations. Aged animals demonstrating an increased frequency of morphologically abnormal spermatozoa may therefore be simply unable to repair gene damage responsible for sperm head morphology.

Mice treated with chemical mutagens and radiation have an increased incidence of morphologically abnormal spermatozoa (Wyrobek \& Bruce, 1975). This incidence is dose-related and appears to be genetically inherited (Staub \& Matter, 1976; Hugenholtz \& Bruce, 1977; Wyrobek, 1979). The basis for these abnormal spermatozoa, while not completely understood, may be related to cellular changes caused by chemical carcinogens and/or ageing (Pitot, 1978).

The mitotic studies revealed differences in frequency of chromosome aberrations in the 2-month-old mice when compared to the other groups. This technique was included in this study to compare ageing effects using two independent measurements. From these results for the C57BL/6 mouse strain, sperm morphology assessment appears to be a more sensitive technique to monitor ageing effects than is analysis of the frequencies of chromosomal aberrations.

The same mutagenic exposure which might increase the frequency of mutation for genetic diseases could also act on the genes responsible for determining sperm head shape, thus 
increasing the numbers of spermatozoa with abnormalities, but this is a very difficult theory to test. The present results, however, certainly demonstrate a significant increase in the frequency of abnormal spermatozoa as a function of paternal ageing and this increase may be due to environmental factors or an inherent susceptibility to mutation in the ageing germ cells. It is not known, however, exactly what percentage of these abnormal spermatozoa are actually capable of entering the oviduct and fertilizing the ovum. Krzanowska (1974) reported that C57BL/Kw mice contain fewer abnormal spermatozoa in the oviduct than in the uterus.

Neaves \& Johnson (1981) studied 4- and 21-month-old mice and reported differences in the thickness of the tunica albuginea and a significant decline in Leydig cell number with advancing age. The incidence of atrophic seminiferous tubules increases with age in men (Honoré, 1978; Hatakeyama, Takizawa \& Kawahara, 1979) and CBA/Ca mice (Gosden, Richardson, Brown \& Davidson, 1982). The lack of spermatogenesis in some seminiferous tubules of 25 -month-old C57BL/6 mice could be explained by a decline in testosterone levels as reported for $\mathrm{CBF}_{1}$ (Bronson \& Desjardins, 1977) and CBA/Ca (Gosden et al., 1982) strains.

\section{References}

Alexander, P. (1967) The role of DNA lesions in the processes leading to aging in mice. Symp. Soc. Biol. 21, 29-50.

Archarya, P.V.N. (1972) The isolation and partial characterization of age correlated oligo-deoxyriboribonucleotides with covalently linked aspartylglutamyl polypeptides. Johns Hopkins Med. J., Suppl. 1, 254-260.

Bennett, J.W. \& Abroms, K.I. (1979) Gametogenesis and incidence of Down Syndrome. Lancet 2,913.

Bronson, F.H. \& Desjardins, C. (1977) Reproductive failure in aged $\mathrm{CBF}_{1}$ male mice: interrelationships between pituitary gonadotropic hormones, testicular function, and mating success. Endocrinology 101, 939-945.

Curtis, H.J. \& Miller, K.J. (1971) Chromosome aberrations in liver cells of guinea pigs. J. Geront. 26, 292-293.

Erickson, D. \& Cohen, M.M. (1974) A study of parental effects on the occurrence of fresh mutations for the Apert syndrome. Ann. Hum. Genet. 38, 89-96.

Gosden, R.G., Richardson, D.W., Brown, N. \& Davidson, D.W. (1982) Structure and gametogenic potential of seminiferous tubules in ageing mice. J. Reprod. Fert. 64, 127-133.

Hatakeyama, S., Takizawa, T. \& Kawahara, Y. (1979) Focal atrophy of the seminiferous tubule in the human testis. Acta Path. Jap. 29, 901-910.

Honoré, L.H. (1978) Ageing changes in the human testis: a light-microscopic study. Gerontology 24, 58-65.

Hugenholtz, A.P. \& Bruce, W.R. (1977) Transmission of radiation-induced elevations in abnormally shaped murine sperm. Proc. 8th Ann. Meet. Environ. Mutagen Soc., Denver p. 75, Abstr.

Kram, D., Schneider, E.L., Tice, R.R. \& Gianas, P. (1978) Aging and sister chromatid exchange. I. The effect of aging on mitomycin $\mathrm{C}$ induced sister chromatid exchange frequencies in mouse and rat bone marrow cells in vivo. Expl Cell Res. 114, 471-475.
Krzanowska, H. (1972) The influence of age on the proportion of abnormal spermatozoa and on fertilization rate in inbred and $F_{1}$ hybrid male mice. Acta biol. Cracov. (Ser. Zool.) 15, 131-135.

Krzanowska, H. (1974) The passage of abnormal spermatozoa through the uterotubal junction of the mouse. J. Reprod. Fert. 38, 81-90.

Krzanowska, H. (1981) Sperm head abnormalities in relation to the age and strain of mice. J. Reprod. Fert. 62, 385-392.

Latt, S.A. (1974) Sister chromatid exchanges, indices of human chromosome damage and repair, detection by fluorescence and induction by mitomycin C. Proc. natn. Acad. Sci. U.S.A. 71, 3162-3166.

MacLeod, J., \& Gold, R.Z. (1953) The male factor in fertility and infertility. VII. Semen quality in relation to age and sexual activity. Fert. Steril. 4, 10-33.

Murdock, J.L., Walker, B.A. \& McKusick, V.A. (1972) Parental age effects on the occurrence of new mutations of the Marfan syndrome. Ann. Hum. Genet. 35, 331-336.

Natoli, A., Riondino, G. \& Brancati, A. (1972) Studio della funzione gondale ormonica e spermatogenetica nel corso della sensecenza maschile. G. Geront. 20 , 1103-1119.

Neaves, W.B. \& Johnson, F. (1981) A comparative analysis of age-related fibrosis in the tunica albuginia of mice, rats and humans, with a preliminary assessment of Leydig cell numbers in aging mice. Anat. Rec. 199, 181A, Abstr.

Pitot, H.C. (1978) Interactions in the natural history of aging and carcinogenesis. Fedn Proc. Fedn Am. Socs exp. Biol. 37, 2841-2847.

Price, G.B., Modak, S.P. \& Makinodan, T. (1971) Age-associated changes in the DNA of mouse tissue. Science, N.Y. 171, 917-920.

Schneider, E.L. \& Gilman, B. (1979) Sister chromatid exchanges and aging. III. The effect of donor age on mutagen-induced sister chromatid exchange in human diploid fibroblasts. Hum. Genet. 46, $57-63$. 
Schneider, E.L. \& Monticone, R.E. (1978) Aging and sister chromatid exchange. II. The effect of the in vitro passage level of human lung fibroblasts on baseline and mutagen-induced sister chromatid exchange frequencies. Expl Cell Res. 1115, 269-276.

Smith, C.A.B. (1972) Note on the estimation of parental age effects. Ann. Hum. Genet. 35, 337-342.

Sotomayor, R.E., Sega, G.A. \& Cumming, R.B. (1979) An autoradiographic study of unscheduled DNA synthesis in the germ cells of male mice treated with $\mathrm{x}$-rays and methyl methane-sulfonate. Mut. Res. 62, 293-309.

Staub, J.E. \& Matter, B.E. (1976) Heritable reciprocal translocations and sperm abnormalities in the $F_{1}$ offspring male mice treated with triethylenemelamine (TEM). Arch. Genetik 49, 29-41.
Tunte, W., Becker, P.E. \& Von Knorre, G. (1967) Zur genetik der myositis ossificans progressiva. Humangenetik 4, 320-351.

Wyrobek, A.J. (1979) Changes in mammalian sperm morphology after $\mathrm{x}$-ray and chemical exposures. Genetics, Princeton 92, 105-119.

Wyrobek, A.J., \& Bruce, W.R. (1975) Chemical induction of sperm abnormalities in mice. Proc. natn. Acad. Sci. U.S.A. 72, 4425-4429.

Wyrobek, A.J. \& Bruce, W.R. (1978) The induction of sperm-shape abnormalities in mice and humans. In Chemical Mutagens: Principles and Methods for Their Detection, Vol. 5, pp. 255-285. Eds A. Hollaender \& F. J. de Serres. Plenum Press, New York.

Received 15 January 1982 